\title{
Beginner Adult ESL Education in the Age of Technology
}

\author{
Abdulaziz Aljabre ${ }^{1}$ \\ ${ }^{1}$ Frederick, Maryland, USA \\ abdulazizaljabre@hotmail.com
}

\begin{abstract}
The interconnectedness of technology and education is visible in all disciplines, especially in language learning. English as a Second Language (ESL) has long made use of technology to create meaning and deepen understanding for English Language Learners. Technology is also used as a means to further learning through language programs and multimodal assignments. However, adult refugee and immigrant students at community colleges often have had little to no exposure to technology. Yet, these students face the challenge of acclimating to life as a student, while learning a new language. Instructors of ESL can help these students with their language needs and development as students by introducing technology instruction into the curriculum. It is the author's claim that technology instruction should be incorporated into ESL instruction at the beginner level. This paper outlines the need for technology in ESL instruction and provides a paradigm for carrying out such instruction.
\end{abstract}

\section{KEYWORDS}

Technology, English as a Second Language, Adult Education, Community Colleges, English Language Learners

\section{INTRODUCTION}

I recently had the opportunity to observe an ESL class, and as a former ESL student myself, I was interested to see the teaching methodology implemented in terms of technology education. The class observed was a beginning level ESL class with twenty students. The students, aside from two international students, were all in their late thirties and well into their sixties. They had all lived in the United States for at least seven years and upwards to thirty year and worked at a factory on an assembly line. They had limited communication skills and little to no writing skills. Their daily class was three hours long and covered all skills. The last hour of the Friday class was designated as a laboratory hour, which in this case, the class moved to a computer laboratory. While the rest of the class ran smoothly with the students actively participating and demonstrating their understanding, the last hour proved to be quite a challenge.

Upon arriving to the computer laboratory, the students were told to turn on the computers and log on using their unique username and password. This task was daunting. Although the students in the previous weeks were shown how to log on the computer and wrote down their username and password in their notebook and even practiced it, it seemed as if the students had forgotten everything. The teacher moved from student to student assisting and correcting usernames and passwords that were typed incorrectly. For some of the students who remembered how to log on, using the keyboard was the challenge. For others, clicking the mouse, what many of us consider to a simple task, was more than an obstacle. Although the students had been in the computer laboratory before, it seemed as if they had never seen a computer before. For many of the

DOI : 10.5121/ijait.2012.2101 
students, this is not far from the truth. As a result, this observation raised many questions in my mind about the success of the students and their interactions with technology. Without technology can these students be successful in their education? How are these students going to be able to learn about technology? And what is the best way to integrate technology into their lessons without taking away from the set curriculum?

Technology has undoubtedly changed the way students learn and in turn the way that teachers teach. The use of technology has created an ease of learning and teaching for many. However, this technology has also created a barrier that many must attempt to overcome. The 'digital divide,' as it has been termed, signifies the division between the haves and the have nots, but there is also a division between the technologically literate and the non-technologically literate [1]. In the world of English as a Second Language (ESL) learning, technology plays an array of roles. From the use of media playing devices, such as CD and MP3 players, to the use of computers and smartboards to assist learning, technology is a vital aid in the ESL classroom. The importance of using technology in teaching and learning a second language has been previously noted [2] [3] [4] [5]. Technology helps to deepen understanding and facilitate transfer through the use of images, sounds, and interactive exercises and experiences.

Yet, here lies the problem: many English language learners (ELLs) studying in the United States come from countries with underdeveloped technology education or, as in the case above, many Adult students who have immigrated to the United States have spent much of their time in the United States working to not only support themselves, but often times they support family members remaining in their native country. Moreover, while working and living in the United States, they have remained in communities amongst other speakers of their language. Technology for many adult ELLs has been of little importance. This is explicitly true for the population of students on which this paper is based.

\section{DeSCRIPTION OF ESL STUdents IN COMMUNiTy COLLEGES}

Community college campuses usually house different types of students than traditional colleges and universities. That is not to say that either student is better or worse than the other, but they often have different goals and many students at community colleges are classified as nontraditional students [6]. Aslainan, as cited by [7], stated that the nearly "42 percent of all students at both private and public institutions are age 25 or older" What's more is that number of adult students in higher education has increased $170 \%$ between 1970 and 2000 [7]. In community colleges, adult students, who are thirty years and older, make up 36 of the student population [8]. Community college students often fall into one of several categories; 1 ) those who transfer to a four year college after earning an associate's degree; 2) adults returning to college either to take a few courses or to earn an associate's degree; 3) ELLs of all ages wishing to improve their language skills. Our focus falls on the last category, ELLs wishing to improve their language skills.

Within the category of ELLs attending community colleges there still remains a diverse population with diverse backgrounds and histories. Unlike many universities whose ELL population consists mainly of international students, ESL instructors at community colleges find themselves working with many refugee and immigrant students, and international students alike [9]. However, refugee and immigrant often have different goals and measures for success than international students [10] [9]. International students' goal during their time in ESL classrooms is usually to learn academic English that vital to their success in mainstream courses required for their degree. Whereas, aside from learning academic English later in their ESL career, it is of the utmost importance that refugee and immigrant students acquire basic interpersonal communication skills (BICS) needed to survive in the United States. The BICS of refugee and 
International Journal of Advanced Information Technology (IJAIT) Vol. 2, No.1, February 2012

immigrant students goes beyond hellos and goodbyes and asking for help and must include different realms such as talking to their child's teacher or calling in late for work.

International students also must acquire BICS, but it is international students who more often than not have had exposure to English as a Foreign Language (EFL) courses in their native countries. Aside from EFL courses, many four year colleges and universities insist that students enter with a certain level of English language proficiency commonly demonstrated through the Test of English as a Foreign Language (TOEFL) or the International English Language Testing System (IELTS). On the other hand, most community colleges welcome students who are described as having zero level and in need of the most basic and beginner level of ESL instruction [9].

Many of the students classified as being either refugee or even immigrant have had disrupted education many times as a result of war, natural disasters, native culture, or poverty. These students are often required to sacrifice their education for the good of their family. In times of war, education is of little importance and rightfully so. For some refugee students their education may have stopped during primary school or for others they may have completed primary school and maybe even secondary school. As a result, the students' knowledge of their first language (L1) is underdeveloped usually in terms of writing and reading and their speaking ability may mostly be colloquial with a limited ability to make use of formal language [11]. Moreover, immigrant and refugee students can come from some of the poorest nations where citizens have little exposure to technology, even in its most basic form.

\section{USE OF TECHNOLOGY IN THE ESL ClASSROOM}

As a result of the little to no exposure to technology in their native countries, immigrant and refugee students are faced not only with the challenge of learning how to use technology, but also the task of doing so without any transfer of knowledge from their L1. The use of technology in any classroom has served both teachers and students offering ease and accessibility. The use of Blackboard, wikis, blogs, and other Internet tools have taken the classroom out of its original rigid context and made it flexible. Likewise, the use of technology in the ESL classroom has created flexibility, but is also used as a means to create meaning for ELLs.

Visual aids have long proven themselves as a necessary tool for ESL instructors [12] [13]. Technology brings life to visual aids. Visual aids, that were once two dimensional both flat and boring, come to life with technology. Movement and sound allows for ease of transfer and deepens connections to enhance the learning experience. Technology does not replace realia or authentic experiences, but can help to replicate them when the real thing is unobtainable [12]. Moreover, technology introduces a new type of literacy to students. Class wikis and blogs require students to consider a wider audience. The audience is no longer merely the instructor, but includes the students' peers and maybe even the entire World Wide Web. The shift in audience results in a shift in tone and style which broadens the students' writing and reading abilities [14].

Moreover, multimodal assignments are increasingly popular in the ESL classroom combining technology with other modes of communication [15] [16]. Multimodality introduces students not only to a wider audience, as technology can do on its own, but helps students to translate their work to account for audience. Students then develop a range of formality and a deeper understanding of tone as well as audience. ESL students are able to complete multimodal assignments at campus computer laboratories or in a language laboratory if the college or university is equipped with one.

Technology also comes in the simplest forms in the ESL classroom. Instructors commonly make use of CD and DVD players, projectors, Smartboards, and computers. Most instructors have access to computer laboratories or language laboratories. While most computer laboratories 
merely provide connection to the Internet and campus intranet, language laboratories house materials that instructors can make use of as lesson extension or for autonomous learning. Interactive language software allows students to practice grammar, reading, writing, listening, and speaking skills. Despite the massive appeal and use of technology in the ESL classroom, many adult refugee and immigrant ELLs are not able to make use of technology in the simplest forms.

\section{Possible Negative Effects of Limited Technology KnOWLedge}

Oblinger states "The networked world is dominating the economy, increasing the power of the individual, and changing business models - no one can afford to be without computer competence" [7]. Technology affects every area of life. For many of the students technology has played little if any role in their lives. If these students wish to be successful, technology will have to become a skill worth obtaining. However, the students in the aforementioned class only have one computer laboratory hour a week. The students do have access to the college's computer laboratories during their open hours, but as a result of their limited knowledge of technology coupled with their hectic personal lives few, if any, seek out technology on their own. Therefore, the limited use of technology on a college campus results in limited technology skills on behalf of the students. This has a large effect on students who do not have access to technology off campus. Specifically, this affects ESL students who did not have access to technology in their native country and had no use for technology in the workplace or the home in the United States. These students are least likely to seek out and learn new technology on their own or make use of it in their lives when they have survived for so long without it. This of course does not mean that these students are incapable of learning new technology or implementing it in their lives, but for many, formal instruction is needed to facilitate an understanding of the countless possibilities certain technology has. However, for many students a basic understanding of English is necessary in order to grasp technology instruction.

Students can be taught technology instruction in later ESL levels when their language skills have had time to develop. However, with the amount of technology that is used every day in the ESL classroom some students with lower language skills would undoubtedly be left behind in terms of their ability to use technology. This would continue as the students passed into the higher levels, as their class grade would most likely not reflect their ability to use technology if their language skills progressed sufficiently. Especially for adult students with children, many find it easier to have their children help them with their technology issues, as many students feel that learning technology is unrelated to the advancement of their English language skills.

Moreover, if technology is left out of the students' ESL instruction, the students will have a greater struggle when advancing into mainstream college courses. With the large number of students in the community college classroom many instructors depend on technology, including Internet tools and Blackboard, to make tasks, such as collecting homework, administering exams, initiating discussions, and researching topics, easier for both the instructor and the students. Using technology to complete the aforementioned tasks helps to reduce paper use, assert deadlines, check for plagiarism, and of course is necessary for distance learning and online courses. While students may simply decide not to take online courses due to their limited ability to use technology, this is nearly impossible as almost all classes at the college level incorporate technology in some way. Furthermore, many classes are classified as being hybrid courses with select scheduled meeting times not held in the physical classroom, but rather online through the college's Blackboard system. If the students are striving to complete their program or trade, knowledge of technology is crucial. 
Still though, many students may feel that they can wait until entering mainstream courses to take technology courses to advance their knowledge of technology. If the college's ESL program does not incorporate technology into the courses, this may be possible. However, the issue that then arises is a financial one. In the aforementioned case, the students on which this paper is based would then find themselves in a predicament. The students in this case had been previously laid off when their job was outsourced. The students were successfully secured a federal grant to attend the local community college. The students were given an allotted amount of money to finish both the ESL program, regardless of what level they were placed into, and a trade program, such as welding or respiratory therapy. The students would be wasting precious time and money that they unfortunately do not have by waiting to take unnecessary technology courses.

At all levels of a college education technology plays some sort of role. While not all colleges and universities are able to provide its students with the same quality of technology, technology is still a vital factor in the students' education. Technology and ESL education are not explicitly reliant on one another. Success in one realm does not ensure success in the other. However, education and technology have a closer relationship as being technologically literate will create easiness for students. This is not in the sense that the students will be able to grasp the material being taught any better than a non-technologically literate student unless technology is used in the classroom in such a way that differs from their dominant learning style. Being technologically literate will create ease in being a student in this age of technology.

Thus, it is to the benefit of the student that technology be incorporated into the ESL instruction. Some instructors may feel that including technology instruction will take much needed time away from a set curriculum, however including technology instruction will possibly open the students to a new world of language learning. Once students have acquired some technology skills, they may feel empowered to take charge of their own learning. Technology skills will give the students a greater opportunity to be successful students in the future. The technology instruction that these students need does not and should not reflect an undergraduate computer course. The instruction should be a reflection of the students' most basic technology needs.

\section{MeEting the Students' Technology NeEdS}

Beginner students by no means need in depth knowledge of the workings of a computer, but basic technology skills will undoubtedly benefit the students and their education. Non-technologically literate students should be able to use a word document program, a presentation program, such as PowerPoint, an Internet search engine, and the college's email and Blackboard system. The ability to use these basic programs is vital to their ability to survive as students. Although for many of the students, the instruction will need to be even more basic. Therefore, the technology instruction will have to begin at an even more basic level.

Students with no previous exposure to technology will need to learn how to turn the computer on and off, turn the screen on and off, open programs, and adjust the volume. The students will also need simple keyboard lessons. It is unreasonable to think that the students will be able to type so many words per minute using an English keyboard. Yet, students should be taught what the abbreviated words on the keys mean. Alt and Ctrl have no meaning to the students and thus should be explained and practiced in class.

Moreover, simple tasks such as using the mouse should be explained and demonstrated to the students. Many students do not realize that the mouse has two buttons that do different things when clicked. Frustration can easily set in when a student is trying to click on an object repeatedly and a drop-down menu continues to appear and the program fails to open. Instruction on what many consider to be common technology knowledge is exactly what is needed for adult 
ESL students, especially those who have been in the workforce in jobs where technology was absent.

Learning technology can be a frustrating ordeal for any learner, but more so for adult ELL students with little to no technology knowledge in their L1. Students in this situation lack knowledge or even vocabulary to transfer from the L1 to the second language (L2). Therefore, it may prove beneficial to allow the students to mimic the instructor's actions that are projected for all to see using computers that are set to their native languages. This method may be seen as a crutch for students, but in reality it is merely a way to generate and form knowledge that was otherwise lacking. Of course, students can learn to use technology without it being in their native language, but when the focus of the course is not technology, as is the case with ESL courses, then allowing the students to work for a short period of time in their native language should not be seen as a crutch for students when it is just simply a boost for students.

Still though, many ELL students will indeed need a crutch when learning to use technology and receiving instruction in other disciplines also. Dictionaries and translation tools provide that crutch for students; of course students at some point must be taught to use context clues and identify meaning through use. Should the occasion arise when students need to utilize translation tools, online tools offer the students an array of options. Students should be given instruction on how to use different dictionaries, translators, and thesauruses. Allowing the students to make use of these tools will help them to differentiate between the credible tools and the unreliable ones.

Lastly, as the students progress with their language abilities and move to writing sentences and even begin writing paragraphs it is important for the students to be taught how to use a word document and the formatting tools that it offers. Basic word document skills such as opening, saving, and printing a document should be covered. As should other skills including indentation, moving from line to line, adding punctuation, changing the font size, style, and color, and even some shortcut tools such as Ctrl I (italics), Ctrl B (bold), Ctrl U (underline), Ctrl X (cut), Ctrl C (copy), and $C t r l V$ (paste).

Students who are able to successfully do the aforementioned tasks should be able to fulfill the role of student and all that it entails in regards to basic technology. The students' ability to do the tasks does not translate to advanced language ability or knowledge within their specified trade, but will helpfully reduce the stress of being a student in the age of technology.

\section{MeEting the Students' TeChNOLOgy NeEdS}

\subsection{Exercises and Repetitive Tasks}

The idea of learning to use technology is a nightmare for many adult learners, especially as they watch children and young adults pick up on technology with such ease and success. Learning to use technology can be an exhausting task; however it is not an impossible task. Whether beginner technology instruction in happening in the lowest level of ESL instruction or a more advanced course, again the instructor's computer screen should be projected so that all students can view the demonstration to both mimic the instructor's actions and take note of them as well.

After a mini technology lesson has been presented and has been repeated as a class, it is best to let the students practice it on their own. Simple exercises and repetitive assignments can help ease adult ELL learners into using technology. For example, learning to use the mouse is as simple as practicing opening folders with a left click, viewing the icons in the folder as different sizes, and then closing the window again with a left click. Double and single clicks on the mouse can also be taught through simple repetitive exercises that will help students get used to using technology. 
When the students have begun writing sentences and paragraphs, giving the students simple sentences or paragraphs to be copied using different formatting tools will help the students become accustomed to using the application. The same exercises can be done in other programs as well. Simple PowerPoint presentations can be made and presented to the students who take notes on the presentation and the animation using copies of the printed presentation and then replicate the presentation on their own.

Exercises using the institution's email and Blackboard system should also be done to create familiarity with the systems. Giving the students a short writing assignment or asking a question in class that must be answered for homework is a good way to get the students to interact with technology outside of the classroom. Instructors can assign the students a task which is to be completed by sending an email with the answers or completed assignment to the instructor. The issue that can arise from such tasks is that many students do not have access to computers or Internet from their homes. In case this happens, it is suggested that the students have ample time to complete the assignment and go to a computer laboratory on campus to send the assignment. Requiring the students to complete an assignment, as simple as it may be, using the email system will not only reinforce the skills they learned to send the email, but also each step is practiced: turning on the computer, using the mouse and keyboard, opening the Internet, logging on the email system, typing the answer, and sending the email.

Moving on to the institution's Blackboard system may prove to be more of a challenge than the other programs. Blackboard is equipped with so many tools and the uses for those tools are nearly endless. On Blackboard, students should become acquainted with certain sections of the application including Announcements, Grades, Discussion Board, Assignments, and Documents. Some instructors may not utilize some of the tools just mentioned, however if the students are to become competent users of the Blackboard system, then the instructor should make some use of them for teaching purposes. Like the other programs, repetitive exercises will help the students to become familiar with the Blackboard tools and hopefully skilled technology users.

\subsection{Authentic Tasks}

Once the students are able to complete the aforementioned tasks, the skills should be reinforced through more authentic tasks. These tasks should be a simplified reflection of the tasks that they will be required to do in future courses. The authentic tasks should be carried out throughout the semester, so as to not appear to the students as merely being something they need to know for a certain class or something they will be tested on. Also, authentic tasks help them to understand what role technology will play in their lives as students. Moreover, technology is continuously changing and being adapted. Students will need to remain current as different versions of programs are released. Continuous use of the programs will help the students realize and adapt to any changes that are made.

Students should always be conscious of their growth in any discipline. Tracking one's improvements in a course allows the student to not only feel proud of their growth, but also to reflect on the information that was problematic for them. Students can do this by creating a portfolio of their work. Especially in language learning, portfolios benefit the student in many ways. These benefits will not be noted here, but authors have enumerated the benefits of their use [17] [18].

All levels of students can create a portfolio of their work. The portfolio need not be an elaborate or time consuming task. Even creating digital folders that houses the students' work completed throughout the semester will help the student to visualize their progression or lack thereof. These "portfolios" can be kept on thumb drives (USB). If the students do not have access to an external 
storage device, most colleges allow students to save documents and other information to the institution's server. When students log on the institution's computer with their personal username and password, they have will have access to any information that was saved to the drive bearing their name. Each institution has a different name for this personal online storage and the drive letter (example, Hard Disk Drive H: or F:), but the concept is the same. Anything saved in the designated drive will be linked to the student's username and password. Therefore, any time the student logs on to the institution's computer, the student will have access to anything previously saved in the student's designated hard disk drive. This is an easy and quick way to help the students stay organized and track their progression as their skills improve.

Another real life task that students should be taught how to do and continue to practice as their skills develop is sending emails to their instructors. Students are often required to inform the instructor of classes that they will miss or they may need to send a request to the instructor. Instructors with large class sizes many times prefer to communicate through email. This task seems basic enough, however students rarely recognize the shift in style and tone that must occur when addressing an instructor versus a peer.

Providing the students with information on how to address their instructors including salutations, restricted use of informal speech and slang, punctuation, and capitalization will help the students to send appropriate emails. Students should be encouraged to practice this skill throughout the semester and throughout their academic career. The use of email extends beyond academia and well into "the real world."

Lastly, as aforementioned, Blackboard plays a large role within many courses. It serves as a medium through which information can be passed, classes can be carried out, and discussions can be held, among other things. Despite the students' low level of English, Blackboard can still play a large role in the ESL class. The sooner the students feel comfortable using technology such as Blackboard, the sooner they will be able to make the full transition to being a student.

Instructors make use of Blackboard in a variety of ways, but most commonly it is used to post class announcements and grades, hold discussions on specified topics, and submit assignments. Students should have practice with each of these tasks. The discussions that lower level students are capable of generating are not expected to reflect what a mainstream instructor would expect, but the premise is the same. Similarly, students should be directed to check Blackboard regularly for class announcements and information updates.

Authentic tasks in any form, whether involving technology or not, always impact an ELLs language ability by creating meaning and making the lesson relative and applicable. What's more is that authentic technology tasks, though simplified in form, not only contribute to the students' English language proficiency, but also to their transformation into the role of student.

\section{CONCLUSION}

It is the task of college instructors to recognize that adults returning to college are faced with many challenges, one of which is becoming a student regardless of the discipline in which they enter. Additionally, the students must make this change and strive to adapt to using technology. Therefore, Adult ELLs who are not technologically literate have many obstacles in their path to success, all of which can be overcome through direct instruction of the use of common educational technology.

Most students recognize the use of technology in education and understand that their success as a student is in part reliant on their ability to use technology. ESL instructors must in turn recognize 
the relationship between technology and education. Low level ESL instructors may feel that a greater importance lies in other areas such as vocabulary and phonics training. However, ESL instructors are charged with not only the development of the students' language skills, but also with their development as students, who will enter into an array of academic disciplines. ESL programs find themselves housed in different areas depending on the college or university. One area that ESL programs are often found in community colleges is alongside other developmental skills. Therefore, it is vital that instructors focus the development of the student as a whole, which means a student who is prepared to enter mainstream courses with other young adults.

It would be to detriment of the students if ESL instructors felt that their job started and stopped solely with language instruction. Language ability is not merely the ability to speak, listen, read, and write in the traditional form. Technology has transformed language through its many mediums. ESL students, as well as all students, must become familiar and competent technology users to ensure their success as students.

\section{REFERENCES}

[1] Crump, B. \& McIlroy, A., (2003) “The digital divide: Why the 'don't-wants-tos' wont Compute: Lessons from a New Zealand ICT Project”, First Monday, Vol. 8, No. 12, Retrieved from http://firstmonday.org/ issues/issue812/crump/index.html (accessed January 5, 2012).

[2] Carey, S, (2001) "Principles and practice of using interactive international technology for ESL", Selected Papers from the Tenth International Symposium on English Teaching, Taipei, ROC, pp 2129.

[3] Hayward, N. M. \& Tuzi, F., (2003) "Confessions of a technophobe and a technophile: the changing perspectives of technology in ESL", TESOL Journal, Vol. 12, No. 1, pp 3-8.

[4] Hegelheimer, V. \& Fisher, D., (2006) "Grammar, writing, and technology: A sample technologysupported approach to teaching grammar and improving writing for ESL learners", CAILCO Journal, Vol. 23, No. 2, pp 257-259.

[5] Claybourne, T., (1999) "The status of foreign language and technology", Media and Methods, Vol. 36, pp 6-7.

[6] West, G.B., (1999, Summer) "Teaching and technology in higher education: Changes and challenges", Adult Learner, pp 16-18.

[7] Howell, S. L., Laws, R. D., Williams, P. B. \& Lindsay, N. K., (2006) Trends affecting higher education and distance learning, In M. Beaudoin (Ed.), Perspectives on higher education in the digital age. (pp. 227-245). New York, Nova Science Publisher.

[8] Kane, T. J. \& Rouse, C.E., (1999, Winter) "The community college: Educating students at the margin between college and work", The Journal of Economic Perspectives, Vol. 13, No. 1, pp 63-84.

[9] Crandall, J., \& Sheppard, K., (2004) Adult ESL and the community college, Working Paper 7. New York: Council for Advancement of Adult Literacy.

[10] Levine, J. S., (2007) Nontraditional students and community colleges: The conflict of justice and neoliberalism, New York, Palgrave Macmillan.

[11] McBrien, J.L., (2005) "Educational needs and barriers for refugee students in the United States: A review of literature", Review of Educational Research, Vol. 75, No. 3, pp 329-364.

[12] Canning-Wilson, C., (1999) "Using pictures in EFL and ESL classrooms", (ERIC Document Reproduction Service No. ED445526)

[13] Burt, M., Peyton, J. K., \& Van Duzer, C., (2005) How should adult ESL reading instruction differ from $\mathrm{ABE}$ reading instruction? Washington, DC: Center for Applied Linguistics. Retrieved from http://www.cal.org/caela/esl_resources/ briefs/readingdif.html

[14] Kasper, L.F., (2000) "New technologies, new literacies: Focus discipline research and ESL learning communities”, Language Learning \& Technology, Vol. 4, No. 2, pp 105-128.

[15] Shin, D.S. \& Cimasko, T., (2008) "Multimodal composition in a college ESL class: New tools, traditional norms", Computers and Composition, Vol. 25, No. 4, pp 367-395.

[16] Fraiberg, S., (2001) "Composition 2.0: Toward a multilingual and multimodal framework", CCC, Vol. 62, No. 1, pp 100-126. 
International Journal of Advanced Information Technology (IJAIT) Vol. 2, No.1, February 2012

[17] Little, D., (2002) "The European language portfolio: structure, origins, implementation and challenges", Language Teaching, Vol 35, pp 182-189.

[18] Kohonen, V. \& Pajukanta, U., (2001) “The European language portfolio - making language learning more visible through student reflection", Auckland: ICEL 6 Conference proceedings (in press).

\section{Author}

Abdulaziz Aljabre, originally from Dammam, Saudi Arabia, is pursuing his Master's degree in Management of Information Technology at Hood College in Frederick, Maryland. He received his Bachelor's degree in Computer Science from the University of Findlay in Findlay, Ohio. His research interests include telecommunications, artificial intelligence, virtualization, and educational technology. He is the author of other articles such as "Cloud Computing for Better Business Value" and "Saudi Arabia Censorship: A Model for Workplace Productivity." He is a member of the Association for Computing Machinery, IEEE, and the Association of Technology, Management, and Applied

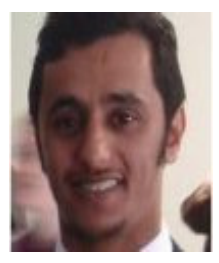
Engineering. 